\title{
Developing an RME Teachers Book Using Scientific Approach of 2013 Curriculum
}

\author{
Dian Armanto ${ }^{1}$, Elvi Mailani ${ }^{2}$, Edy Surya $^{3}$ \\ \{elvimailani@gmail.ac.id\} \\ Mathematic Education,Faculty of Natural Science, Medan State University, Medan Indonesia ${ }^{1}$, \\ Elementary Teacher Education, Faculty Of Education, Medan State University, Medan Indonesia ${ }^{2,3}$
}

\begin{abstract}
This study aims to develop a realistic mathematics teacher's book using the 2013 curriculum scientific approach for grade V elementary / MI students that can be used by teachers to help improve the quality of mathematics learning at the elementary level in North Sumatra. The specific objectives of this research are: developing a class V realistic mathematics teacher's book using the 2013 curriculum scientific approach. This study uses a developmental research oriented on product development where the development process is described as accurately as possible and the product is finally evaluated. Van den Akker (1999) called it formative research where the research activities were carried out in a cyclic process and aimed at optimizing the quality of product implementation in certain situations. The subject of this research is the public and private fifth grade students of SD / MI in North Sumatra. This research was carried out in 2 (two) stages. In the first stage an initial analysis and validation was carried out by a team of experts and experts and a draft of a realistic mathematics teacher's book model was developed using the 2013 curriculum scientific approach for grade V elementary school. 2013 scientific curriculum which is thought to be effective in analyzing knowledge and weaknesses in the mathematics of North Sumatra elementary / MI students.
\end{abstract}

Keywords: Teacher's book, PMR, scientific

\section{Introduction}

The 2013 curriculum is often referred to as a character-based curriculum. This curriculum is a new curriculum issued by the Ministry of Education and Culture of the Republic of Indonesia. 2013 curriculum itself is a curriculum that prioritizes understanding, skill, and character education, where students are required to understand the material, are active in the process of discussion and presentation and have good manners and discipline. This curriculum officially replaces the Education Unit Level Curriculum that has been implemented since 2006. not only that, this curriculum also has weaknesses and advantages.

In the 2013 curriculum, subjects must be followed by all students in one education unit in each unit or level of education. As for the elective subjects followed by students, chosen according to their choice. Based on Permendikbut No. 24 of 2016, it was stated that the implementation of learning in Elementary Schools / Madrasah Ibtidaiyah (SD / MI) was carried out in a thematic-integrated learning approach, except for Mathematics and Physical and Sports Physical Education (PJOK) as stand-alone subjects. for grades IV, V, and VI.

Mathematics learning is one of the subjects that students must learn in elementary school / madrasah Ibtidaiyah (SD / MI). In mathematics education, the mindset is developed 
continuously because mathematics is a science that has a strong and clear structure and relationship between one concept and another. The rules and rules that apply in mathematics are arranged in strict and complete language (not containing multiple meanings) so that users can communicate their ideas in a more practical, systematic, and efficient manner. Thus it is clear that students who learn mathematics will develop not only mathematical knowledge but also the ability to communicate, reason, and solve problems, as well as their personality attitudes. Degeng States that individuals have the power to change themselves, and the task of education is to explore these potentials and give them opportunities to develop [1].

This change in learning paradigm makes the role of teachers and students change. Now, the main subject of learning is students, while the teacher is just a facilitator

But in reality based on the results of learning observations conducted in several elementary schools in North Sumatra, it shows that the focus of the school's attention in overcoming low student achievement is only on teaching method factors and curriculum problems. Especially when viewed from the results of a low national exam specifically on mathematics subjects, then that tends to be a study material and highlighted attention to how the teacher teaches and the learning model carried out, as well as the applied curriculum whether it is good or not. In addition the results of diagnostic tests that have been carried out at the sample school identify the causes of difficulties and the emergence of errors in elementary school students in solving math problems.

Many other factors cause low ability of students to work on questions and understanding mathematical concepts. If you talk about the method and the method of teaching the teacher that is still not in accordance with what is expected, of course you cannot blame the error only on a teacher who teaches in the classroom. Fulfillment of supporting facilities and facilities needed by the teacher in teaching in the classroom must also be considered. Book one of them. Since the 2013 curriculum was implemented coupled with the separation of mathematics lessons for grades IV, V and VI made the problem of this book even more complicated. The problem of the handbook for teachers, especially mathematics textbooks becomes a serious problem that must be solved immediately if the quality of mathematics learning wants to be improved.

From the explanation of the above problems, the researcher is interested in conducting a study that aims to create a teacher's book that will be used by the teacher to teach class $\mathrm{V}$ math using the 2013 curriculum. This needs to be done so that the mathematics learning process can run well, what becomes demands in mathematics lessons can be achieved by students and finally an increase in the competency of the students themselves.

Of the various problems described above, the focus of the problem that will be examined in this study is limited to the development of teacher books on mathematics learning based on realistic mathematics using the 2013 curriculum scientific approach. The formulation of the problem that can be developed from the limitation of the above problem is how the effectiveness and usefulness of the teacher's book of mathematics lessons based on realistic mathematics uses the 2013 scientific approach to the curriculum

This research aims to :

1. Developing a teacher's book learning mathematics based on realistic mathematics using the 2013 curriculum scientific approach.

2. Validating the teacher's book learning mathematics based on realistic mathematics using the 2013 curriculum scientific approach to get good book quality. 


\section{Literature Review}

\subsection{Books and Teaching Materials}

According to Prastowo lesson textbooks are books that contain knowledge, developed based on basic competencies in the curriculum, and used by students to study [2]. There are three ways that teachers can use in compiling textbooks, namely repackaging information, writing themselves, and rearranging. Textbooks can also come from research results. Efforts that can be made to make research-based textbooks are the way the author must first do research and report the results of his research.

Good textbooks or textbooks according to Akbar have several characteristics, namely (1) accurate, (2) appropriate, (3) communicative, (4) complete and systematic, (5) oriented to student centered, (6) siding with the ideology of the nation and state, (7) the rules of the language are correct, and (8) are legible. The existence of basic competencies (KD) and learning objectives that must be achieved by students, has forced the teacher to develop teaching materials in accordance with this. Teaching materials will be more meaningful if the material contains contextual content and is in the student's daily environment [3].

\subsection{Teacher's Book}

The Teacher's Book is a guide for teachers in carrying out classroom learning. The teacher's book used by the teacher will help the teacher carry out each step in the learning process for his students. Step by step activities that will be carried out by students will be contained in the teacher's book. The following is an explanation of the teacher's book function.

\subsubsection{As Instructions for Using Student Books}

The teacher must first learn the Teacher's Book. The teacher must find the following information.

- The order of reference material is developed from the Standards of Graduates' Competencies, Core Competencies, and Basic Competencies of each lesson content, which is then integrated into one particular theme.

- The theme network of each theme that contains basic competencies and indicators of each of the learning content that must be achieved.

- Learning disaggregation developed from sub-themes with the aim that teachers can gradually organize the learning process in accordance with the basic competencies that students must master.

\subsubsection{As a Reference Learning Activity in Class}

The Teacher's book presents the following.

- Explain the learning objectives that must be achieved in each lesson from each sub-theme. 
- Describe learning media that can be used in carrying out the learning process so that the teacher has prepared the necessary learning media.

- Explain the steps of learning carried out in carrying out the learning process in order to assist the teacher in developing the learning plan, systematically following the learning steps.

- Explain techniques and assessment instruments that can be used in each learning choice that may have certain characteristics.

- Explain the types of worksheets that are in accordance with the lessons that are in the Student Book.

In addition to teaching and educating, a teacher is also expected to have skills in developing books that can later be used to be a reference and hold on the teacher in teaching and learning activities in the classroom. The development of the teacher's book designed by the teacher itself is believed and proven to be able to improve the ability and competence of students due to the book designed according to the conditions, characteristics of students and the needs where the book was used [4].

\subsection{Realistic Mathematics}

- One of the factors causing the students' lack of understanding of mate-math concepts is the learning pattern implemented by the teacher. Mathematical learning in Indonesia today, "the real world" is only used to apply concepts and less to "real world". When in class learning, everyday children's experiences are used as inspiration for the discovery and construction of concepts (memematematisasi daily experience) and reapplying to the "real world" the child will understand the concept and can see the benefits of mathematics [5].

- In realistic mathematics learning, students learn to memorize contextual problems. In other words, students identify that contextual questions must be transferred into mathematical form questions to be further understood, through scoring, formulation and visualization. This is a horizontal mathematical process. Whereas vertical mathematics, students complete mathematical forms of contextual problems using concepts, operations and mathematical procedures that are applicable and understood by [6]

- The main activities carried out in Realistic Mathematics Education include: finding contextual problems / problems (looking for problems), solving problems (problem solving), and organizing teaching materials (organizing a subject matter) [7].

- This can be in the form of realities that need to be organized mathematically and also mathematical ideas that need to be organized in a wider context. Organizing activities like this are called mathematical. Realistic mathematics learning has five characteristics, namely:

- use real contexts for students as a starting point for learning

- use the model as a bridge between real and abstract that helps students learn

- mathematics at different levels of abstraction.

- use students' own production or strategies as a result of them "doing mathematics".

- interaction is important for learning mathematics between teachers and students, students and students.

- the relationship between mathematical units and the problems that exist in this world. 


\subsection{Scientific Approach 2013 Curriculum}

Nurul mentions Scientific-oriented learning is learning that uses scientific approaches and inquiry, where students play directly both individually and in groups to explore concepts and principles during learning activities, while the teacher's task is to direct the learning process carried out by students and provide corrections to concepts and principles obtained by students [8].

Learning with a scientific approach is learning that consists of observing activities (to identify the things you want to know), formulating questions (and formulating hypotheses), trying / collecting data (information) with various techniques, associating / analyzing / processing data (information) and draw conclusions and communicate results that consist of conclusions to obtain knowledge, skills and attitudes. These steps can be continued with creating activities.

The principles of learning activities with the 2013 curriculum scientific approach are: (1) students are facilitated to find out, (2) learners learn from various learning sources, (3) the learning process uses a scientific approach, (4) competency-based learning, (5) integrated learning, (6) learning that emphasizes divergent answers that have multi-dimensional truths, (7) applicative skill-based learning, (8) improved balance, continuity, and linkages between hard-skills and soft-skills, (9) learning that prioritizes civilizing and empowering students as lifelong learners, (11) learning that takes place at home, at school, and in the community, (13) recognition of individual differences and cultural backgrounds of students; and (14) the learning atmosphere is fun and challenging.

The curriculum objectives include four competencies, namely (1) spiritual attitude competencies, (2) social attitudes, (3) knowledge, and (4) skills. This competence is achieved through the process of intracuricular, co-curricular and / or extracurricular learning. Spiritual Attitude Competency Formulation is, "Receiving, carrying out, and respecting the teachings of the religion he adheres to". The formulation of Social Attitude Competence is, "Shows honesty, discipline, responsibility, courtesy, caring, and confidence in interacting with family, friends, teachers, and neighbors and love the motherland". Both of these competencies are achieved through indirect teaching, namely exemplary, habitual, and school culture with regard to the characteristics of subjects, as well as the needs and conditions of students. The growth and development of attitude competencies is carried out throughout the learning process, and can be used as a teacher's consideration in developing students' character further.

The process of learning mathematics is done through empowering the four basic pillars of education [9]. Empowering students' abilities to be willing and able to do to enrich their learning experience (learning to do) by increasing interaction with their environment both physically, socially and culturally so as to build their understanding and knowledge of the surrounding world (learning to know). It is hoped that the results of these interactions can develop knowledge and self-confidence (learning to be). The opportunity to interact with other individuals in various groups (learning to live together) will shape their personality to understand plurality and generate positive and tolerant attitudes towards diversity and differences in life.

\section{Research Methods}

This chapter discusses systematically the method of developing teacher books and student books based on realistic mathematics using the 2013 curriculum scientific approach. 
The targeted research products in the first year of this research are limited to the initial models of teacher books and student books based on realistic mathematics using a scientific approach using the 2013 curriculum valid.

\subsection{Types of Research}

This study uses development research methods to identify that developmental research is oriented towards product development where the development process is described as accurately as possible and the product is finally evaluated (Richey and Nelson 1996). This research is also referred to as formative research where research activities are carried out in a cyclic process and are aimed at optimizing the quality of product implementation in certain situations [10]. In mathematics learning, this development research is applied in the repetitive activities of designing and testing the material products of mathematics learning [11]. The results of this study in the form of quality products theoretically, procedural methodology, and empirical.

This research activity was carried out in 2 (two) stages. Both stages are described as follows:

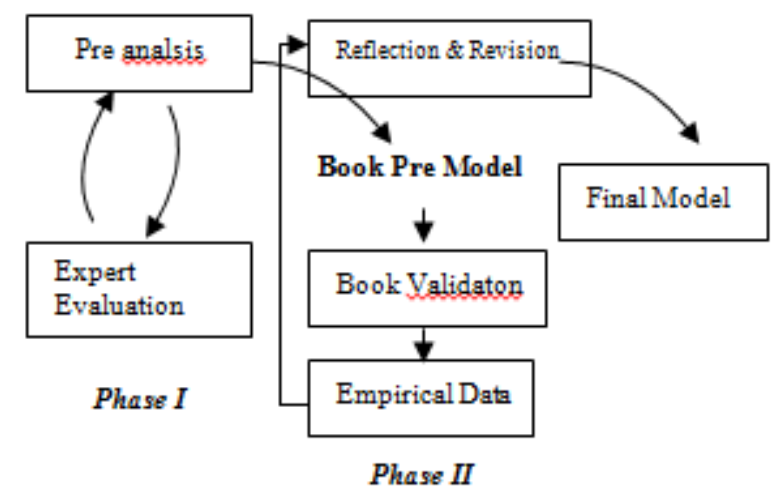

Fig 1. Development research activities and stages

Phase I of this study is called the front-end analysis phase which is intended to analyze and determine the mathematics based teacher's book using the 2013 curriculum scientific approach. This activity is followed by developing materials that are in accordance with each basic competency in mathematical material. Through justification, analysis and evaluation of competent mathematics education experts and elementary school teachers, the Preliminary Model of the teacher's book for mathematics lessons based on realistic mathematics was developed using the 2013 scientific approach to curriculum in grade V elementary school. This study involved experts in the development of mathematics education from the North Sumatra Province Education Agency and other mathematical learning experts. Phase I activities are carried out within the first 6 months of this study.

Data for stage I development of teacher books based on realistic mathematics using the 2013 curriculum scientific approach was generated by validation conducted by teachers, principals and 3 lecturers from Medan state universities. Validation is carried out using a validation format that has been prepared by the expert team. The aspects that become references to teacher book validation and student books based on realistic mathematics using the 2013 curriculum scientific approach are: 
- Feasibility of content consisting of: (a) suitability of material content with SK and KD, (b) accuracy of material, (c) updating of material, (d) encouraging curiosity, (e) training and tests, and (f) enrichment

- Feasibility of presentation which includes: (a) presentation techniques, (b) presentation support, (c) learning support, (d) coherence and literacy of the mindset.

- Feasibility of language which includes: (a) accuracy, (b) communicative, (c) suitability of language rules, (d) suitability of students' development.

The description of the teacher book research activities based on realistic mathematics uses the 2013 scientific scientific approach. Phase 1 research activities were carried out in Medan from April to August 2018. This study involved a validator team consisting of 3 mathematics education experts and 5 teachers.

The research activity began with the objective analysis activities held on April 2, 2018. This objective analysis was carried out to establish the basic direction and main objectives of development so that it could become the main benchmark in developing the teacher's book and the fifth grade mathematics student book. appropriate learning. In carrying out the analysis of objectives, viewed from the 2013 curriculum aspect. The subject that was developed in the teacher's book and the student's book was all the material contained in class V in the 2013 curriculum.

After the analysis of the objectives has been completed, on April 4, 2018 an analysis of the characteristics of students is carried out. Analysis of student characteristics is carried out through a study of student characteristics which include the level of cognitive development, ability, knowledge background, and socio-cultural background of students. From the results of this analysis will later be used as a reference frame in compiling textbooks and student activity sheets. In this study, the subjects were fifth grade students of all elementary schools who were given diagnostic tests in the 10-11 year age range.

The next activity in step 1 is an analysis of teacher needs. Teacher needs analysis was carried out on April 5, 2018. Teacher analysis was carried out through the study of teacher needs which included the learning tools needed to achieve the learning objectives. From the results of this analysis will later be used as a reference frame in compiling the teacher's book. Teacher needs now is a teacher's book that is in accordance with the curriculum that is being used so that the teacher is easy to convey material and concepts to students, it is necessary to develop teacher books and student books especially the mathematics material contained in class V.

The next activity carried out was the analysis of tasks and the sequencing of concepts. This activity was held on April 6, 2018. Task analysis was used to detail the contents of the subject matter in the form of outlines of the subject matter. This activity is carried out by identifying the structure of the subject chosen. In this case, the subject matter contained in the 2013 curriculum. After the task analysis was completed, it was continued by arranging the sequence of concepts that would be taught in realistic math class V teacher books using the 2013 curriculum scientific approach. The purpose of this step was to establish a concept hierarchy will be discussed in the process of learning and teaching. The concept or material must be truly considered so that all are arranged based on the knowledge or skills mastered by students in the previous lesson or at a stage earlier than the lesson.

The next stage of activity is Formulating learning objectives and developing validation instruments. This activity is carried out through the activity of analyzing the lesson concepts and indicators that have been set in the previous activities. From the results of the analysis of 
the concepts and indicators, the learning objectives will be formulated. Furthermore, the preparation of validation instruments was carried out through the activity of designing a measuring instrument that would be used to assess the quality of the teacher's book based on references and input from a team of experts and mathematicians. The validation instruments that will be used are expected to become filters so that the developed teacher's books become more qualified.

The most important activity in this study is the drafting of a teacher's book based on realistic mathematics using the 2013 curriculum scientific approach (11 April - 15 July 2018). This activity is carried out step by step so that the teacher's book is designed in accordance with the references, concepts, indicators that have been developed and all the criteria that have been established in the design of this teacher book.

After the draft of the teacher's book was developed, the next activity was to validate the draft of the teacher's book, validation activities carried out by the validator team that had been appointed in this study. In validating the teacher's book, the validator team used a validation sheet that had been developed and designed in the previous activity. This validation activity aims to produce an effective teacher book draft and can help class V students to improve their competence in mathematics subjects. The validation activity of the teacher book draft was held on July 20, 2018.

\section{Results And Discussion}

\subsection{Validation Results of the Expert Team}

Validation is carried out by teachers and a team of experts from universities. The validator team validated using a validation sheet which was prepared in the mathematics teacher book development research based on realistic mathematics using the 2013 scientific approach to the curriculum. The validation results conducted by the validator team showed that the draft mathematics teacher book based on realistic mathematics using the 2013 curriculum scientific approach was good category. There are only a few in certain parts that must be revised and improved by the development team. Some input from the expert team as the validator team for teacher books and student books were developed including: (a) The use of spelling that is still not consistent, (b) Strengthening for each material taught at the end of the lesson still needs improvement, and (c) more examples to facilitate student understanding.

In general, the validation results of the validator team for the development of mathematics teacher books based on realistic mathematics using the 2013 curriculum scientific approach can be seen below:

\subsubsection{Feasibility of Content}

a. Compliance with material descriptions with $\mathrm{KD}$

The development of the material in the teacher's book is in accordance with the KD contained in the 2013 curriculum. In addition the depth of material outlined is in accordance with the child's development at the elementary school level.

b. Material accuracy 
The material presented is very accurate and by showing the accuracy in applying the concept of geometry in flat building in a simple, clear, easy to understand, and appropriate usage according to the subject matter, the material is presented using standard Indonesian.

\section{c. Material update}

The material presented is up to date in accordance with the latest mathematical developments. Materials, examples, and exercises are appropriate and correct reflecting current events, events, or conditions. In addition the examples given are in accordance with the development of mathematics

d. Encourage curiosity

Descriptions, exercises or examples of cases presented encourage students to do it further and foster creativity. There are questions that can encourage students' desire to seek further information.

e. Exercises and Tests

The exercises are presented in the form of communicative patterns and exercises to master the material being taught. Besides that, the presentation of tests is intended to assess the level of ability of students towards some material that has been taught, and given at the end of each unit.

\section{f. Enrichment}

Enrichment material contains the development of student knowledge and its application in daily life.

\subsubsection{Presentation Feasibility}

a. Presentation Technique

Systematics in the presentation of each chapter contains a concept map, introduction, content, cover and evaluation displayed consistently in each chapter. The description of the chapters is proportional by considering $\mathrm{KD}$ which is supported by several image illustrations in a balanced manner according to the needs of each subject.

b. Presentation support.

Introduction at the beginning of the book contains the purpose of writing, the way to learn that must be followed, thanks, excess books, limited books, and other things that are considered important. Delivering students to know and understand the material that will be presented so as to attract students to learn more about the contents of the book.

c. Learning support.

Presentation of the material places students as the subject of learning. Presentation of the material is interactive and participatory so that the description in the book needs to be supported by activities that are able to form independence for example through independent tasks.

d. Coherence and wrinkling of the thought path 
Submission of material between chapters with adjacent sections reflects the content and relevance of the content. The material presented in one chapter must reflect the unity of meaning and show continuity of meaning so as to form a unified meaning.

\title{
4.1.3 Language Eligibility
}

\author{
a. Accuracy \\ Sentences used to present the contents of a logical text and refer to the Indonesian sentence \\ rules. Languages that are used are straightforward in accordance with students' thinking \\ abilities. Examples can provide abstract concept clarity. The concept description is concrete, \\ students can find it, and if the abstract can be imagined by students

\section{b. Communicate} \\ The message is presented in an interesting language, easy to understand, communicative, and \\ encourages students to read thoroughly. The illustrations presented clarify the material \\ described. Illustration comes from the surrounding environment in accordance with the field \\ of science. \\ c. Compatibility of language rules \\ The sentence used to convey the message refers to the Indonesian grammar rules \\ d. Suitability of student participants' development \\ Language used in explaining a concept in accordance with the development of students and in \\ accordance with the level of emotional maturity of students
}

\section{Conclusion And Suggestions}

\subsection{Conclusion}

1. This study aims to compile a realistic mathematics teacher's book using the 2013 curriculum scientific approach for fifth grade elementary / MI students that teachers can use to help improve the quality of mathematics learning at the elementary level in North Sumatra.

2. The results of the validation of the drafts of realistic mathematics teacher books using the 2013 curriculum scientific approach for SD / MI fifth grade students conducted by the validator team consisting of a team of teachers and lecturers from universities, showed that the designed teacher book was included in the good category.

\subsection{Suggestions}

Revise teacher books and student books based on realistic mathematics using the 2013 curriculum scientific approach in accordance with the input of the validator team. 


\section{References}

[1] Degeng,I.N.S.: Revolusi Mental Dalam Pendidikan untuk Keunggulan Bangsa. Makalah disajikan dalam seminar nasional pendidikan dasar di Universitas Negeri Malang (2015)

[2] Prastowo, A.: Panduan Kreatif Membuat Buku teks Inovatif. Jogjakarta: Diva Press (2015)

[3] Akbar, S.: Instrumen Perangkat Pembelajaran. Bandung: Rosdakarya (2015).

[4] Mailani.E.: Pengembangan Buku Ajar dan Lembar Aktivitas siswa ( LAS ) materi Geometri untuk Siswa kelas V SD Swasta Inti Nusantara Tebing Tinggi Tesis, Medan: Universitas Negeri Medan (2012)

[5] Suharta, I., \& Putu, G.: Pembelajaran pecahan dalam matematika realistik.In Makalah disampaikan pada Seminar NasionalRealistic Mathematics Education (RME) di Jurusan Matematika FMIPA UNESA (Vol. 24) ((2001)

[6] Armanto, Dian.: "Alur Pembelajaran Perkalian dan Pembagian Dua Angka dalam Pendidikan Matematika Realistik (PMR).” disajikan pada Seminar Nasional Pendidikan Matematika Realistik di Universitas Sanata Dharma Yogyakarta (2001).

[7] Fauzan, Ahmad.: “ Pendidikan Matematika Realistik: Suatu Tantangan dan Harapan.”, disajikan pada Seminar Nasional Pendidikan Matematika Realistik di Universitas Sanata Dharma Yogyakarta (2001)

[8] Nurul,H.: Pengertian dan Langkah-Langkah Saintifik.http://www.nurulhidayah.net/879 pengertiandan-langkahpembelajaran saintifik.html\#! prettyPhoto diakses tanggal 19. November (2013)

[9] Puskur.: Kurikulum dan Hasil Belajar. Kompetensi Dasar Mata Pelejaran Matematika Sekolah Dasar dan Madrasah Ibtidaiyah. Balitbang, Depdiknas (2002)

[10] Richey, R. C., \&Nelson, W. A.: Developmental research. Handbook of research for educational communications and technology, 1213-1245.( (1996)

[11] Van den Akker, Jan.: Principles and methods of development research. In Jan van den Akker et al. (Ed.) Design Approaches and Tools in Education and Training pp. 1-14. Dordrecht: kluwer Academic Publishers (1999)

[12] Gravemeijer, Koeno.: Developing realistic mathematics education. Utrecht, The Nederlands: Freudenthal Institute (1994) 